yf yt be contrary yt wyll be full yll payd; were off we put pis mater in my lord, he to be gode lord to vs all.

10. [Also] we present Herre Baby for a pete brybur, and ontrew to hys neypursse.

The Latin version represents the ten articles thus :-

Duodecim jurati pro domino Rege dicunt super sacramentam suum :-

[2]. ${ }^{10}$ quod quedem sewera epud Martenbrig est valde defecta et ruinose in defectum domini abbatis : ideo provideatur pro emenda einsdem.

[3]. Et quod elemosinarius burgi non mundat communem semeram a tenemento Ricardi Bkirmote usque parietem Willelmi Clerke ad grave dampnum et nocumentam communitatis: ideo ipse in misericordis et procuret ${ }^{11}$ emendam citra festum sancti Martini proximum futurum sub pena in capite. ${ }^{12}$

[6]. Item presentant quod Johannes Tendale ${ }^{13}$ infectus est cum infirmitate lepre: ideo preceptum est uxori eiusdem Johannis ut ipse amouest extra domum ad alium locum solitarium quocunque.

[10]. Item presentent quod Henricus Raby est latro communiter de parvis et secretis rebus ad grave $n$ [ocumentum] omninm vicinorum suorum et nichil hsbet de bonis nec catallis sed corpus eius missum est in gaole ${ }^{14}$ domini Regis de Burgo Sancti [Petri].

[1]. Item dicunt quod infra scripti constabularii, decenarii, testores servisie, et supervisores bene et fideliter presentant et preterea que superius patet nullam fecerunt concellamentum. MIArY Bateson.

\title{
Correspondence of Archbishop Herring and Lord Hardwicke during the Rebellion of 1745 .
}

Tere situation of the province of York on the frontier of Scotland frequently compelled its medieval archbishops to exchange the crozier for the sword. In the reign of Edward II Archbishop Greenfield was at one time too busy in repelling Scottish incursions to be able to attend parliament; and his successor, Archbishop Melton, fought \& pitched battle with the invaders, who sorely discomfited him. These old-world times seemed to have returned when, upon the outbreak of the rebellion of 1745 , Archbishop Herring, albeit the meekest of prelates, felt himself enforced to take the lead in organising resistance to the apprehended invasion of the Highland host by enlisting volunteers, convening meetings, concerting measures of defence with the nobility and gentry, and firing the flagging spirit of the country by a famous sermon. This course of action entriled an extensive correspondence with magnates

10 This and the numbers below have been inserted to show the relationship of the paragraphs to those in the English.

11 MS. p'y. 11 ' dim. mar.' is written over the almoner's name.

19 In the margin 'pens c. 8.' 14 Sic. 
in Yorkshire and ministers in London. To none of the latter was the archbishop likely to write with such freedom as to his benefactor Lord Hardwicke, the great chancellor who had made him archbishop of York, and was, much against his own inclination, to make him archbishop of Canterbury. The archbishop's letters to him and copies of his answers are extant among the extensive collection of Hardwicke papers recently acquired by the British Museum, and appear well worthy of publication, at least down to the time when, the invasion heving been repelled and all fear of its renewa] averted, the duke of Cumberland passed through York on his way to take the commend of the army in Scotland. They afford a lively picture of the anxieties, emotions, and multitudinous rumours of the time; reveal the general discontent with the administration; and display the prevailing apathy and incredulity, except on the part of the correspondents themselves, at the beginning of the rebellion, soon passing into lively alarm. It really does seem that, if the rebels had elected to march upon London by way of York instead of by way of Manchester, the lord mayor of York might have been reduced to the alternative, contemplated by the archbishop, of running away or of proclaiming the Pretender. The archbishop himself comes out admirably. Without being precisely a born leader of men, he appears endowed with excellent common sense and moral qualities almost more valuable still : loyal, patriotic, disinterested, indefatigable ; careful of ecclesiastical decorum as a rule, but ready to discard it in cases of emergency; a good hater of his adversaries' principles, but never rancorons towards their persons; and always ready to enliven serious matters by a jocose remark or anecdote.

According to Rastall, who in his history of Southwell has given a pretty full account of Archbishop Herring, ' his politics were monarchical.' This must mean that he esteemed the hereditary title to the crown above the parliamentary; and the assertion is confirmed by the remarkable anecdote told by Hume of Herring's encouragement to him to persevere with his history when the first volume published, comprising the reigns of James I and Charles I, seemed to have fallen dead from the press. As a matter of abstract principle, therefore, his allegiance would have been to the house of Stuart, and Rastall is no doubt correct in holding that the zeal he displayed in the Hanoverian cause 'proceeded not from any speculative opinions of the subject's right to freedom, nor from any very enlarged ideas of the British constitution, but was the effect of religious conviction and of civil allegiance. Herring was sincere in his attachment to the religion he professed, and he believed the support of that religion to be intimately connected with the safety of the family in possession of the crown.' These

1 Add. Mg. 35508.

VOL. XIX.—NO. LXXY. 
letters also show that Herring was as inexorably set as Shakespeare's Faulconbridge against any claimant to the crown who should come with the support of France. As a good Englishmen and a good protestant he sew his daty clearly, and discharged it manfully.

No more amiable and benign prelate than Herring ever sat at York or Canterbury, and the severity of his language towards Roman catholics may occasion surprise. In purely religious matters Herring, like most of the dignified ecclesiastics of his age, was a model of tolerance, and he regarded Roman catholics not as religious dissidents, but as civil enemies. It could not be otherwise while there pas a Roman catholic pretender to the throne: the total overthrow of the Stuart cause had to precede the repeal of those penal enactments which Herring's correspondent, Lord Hardwicke, in a remarkable passage declared to be so inconsistent with the spirit of the age that even in an emergency like that of 1745 it was impossible to put them into effect. The attitude of the rulers of the church is pithily expressed in a letter trom Herring's predecessor, Archbishop Blackburne, to Lord Carlisle, 3 Nov. 1788, printed in the Carlisle papers published by the Historical Mannscripts Commission :-

I am greatly obliged to your lordship for your lind intimation concerning the Roman catholics and the warm alarm they have taken at my procedings. Bat whatever the hot ones among them may threaten of complaints against me on that account, I am in no pain about it. Such of them as are quiet and pescesble will find the Penal Act, for my part, as harmless as they can wrish. But such as can be proved to have been perverting our people from their religion and allegiance must not expeot to be suffered to do it with impunity, but to pay for their unquiet abuse of so much lenity as they enjoy under the present government.

One of the most interesting traits in Herring is his perception of natural beauty, a faculty long dormant in England, and which he was one of the first Englishmen to regain. In his letters to Duncombe his descriptions of Welsh scenery as beheld in his visitation tour (performed on horseback) reveal the same delight in natare as is subsequently met with in the letters of Gray. His considerable literary gift was chiefly expended upon his sermons, but slmost amounts to genius when a picturesque theme presents itself. Goldsmith or Sterne might have envied his picture of a Welsh interior.

The novelty of the thing gave me spirits, and the air gave me appetite, much keener than the knife I ate with. We had musio too, for there came in a harper, who soon drew about us a group of figures that Hogarth wonld give any price for. The harper was in his true place and attitude; a man and woman stood before him singing loudly, 
but not disagreesbly ; a little dirty child was playing with the bottom of the harp; a woman, in a sick night-cap, hanging over the stairs; a boy with crutches fired in a staring attention; and a girl carding wool in the chimney, and rooking a cradle with her naked feet, interrupted in her business by the charms of the music; all ragged and dirty, and all intently attentive.

R. GarnetT.

I.

Lord Hardwicke to the Archbishop of York.

Powis House Aager $811^{245}$ (arrived Sepr $7^{\text {mi }} 1745$ ).

My Lord,-I ought to have thanked your Grace long ago for your last kind letter; bat, though you had the goodness to wish me a speedy deliverance from Chancery, I have been chained to that oar till within this fortnight, and the daily attendance there, together with others of a more disagreesble kind, hindered me from scknowledging that favonr. Since that time, I have (with the interval only of two or three days at Wimple) been confined to this plece, sttending upon my duty of the twentieth part of a Vice-King, and expecting the much wished for arrival of our Principal. In the meantime we are threstened with hoving the disposition of the Kingdom wrested out of our hands, and in the North the storm is gathered. Archbishops of York have before now drawn the secular, as well as the spiritual sword, and I hope your Grace will stand between us and danger. That the Pretender's Son is actually in the Northwest Highlands of Bootland, and that he is joined by some of the clans of Macdonald and the Camerons, mostly papists, I take to be very certain. Infidelity has much prevailed bere conoerning this fact, though I think it is something altered; but I cannot help agreeing with your elder brother of Cant: that in this case, want of faith proceds partly from want of zeal, which in political faith is the worgt source. There seems to be a certain indifference and deadness among many, and the spirit of the nation wants to be roused and animated to a right tone. Any degree of danger at home onght to be vastly the more attended to from the state of things abroed. That I lament from my heart. I think I see the evil ceuse to which it is to be asoribed, and yet I kmow not whether to wish that, by the Public, it should be attribated to that cause. Whare to find a remedy I know not. I 800 only the probebility of one, and am not sure that that will be taken. The success at Capo Breton is very considersble. A vast loss to France, and may be a very great advantege to this country. I wish we had more of these articles to balance the account.

Sir John Cope, with about 2000 more of the King's troops, is I believe now in the Highlands, and I hope his force is sufficient (by the blessing of God) to crush this infant rebellion, provided it be properly exerted before the assistance, which the rebels undoabredly expect from abrosd, can come to them. The Marquis of Tweeddale has this morning received letters from Scotland bringing intelligence from a spy, sent on parpose into those parts, that he had seen this young Pretender, and had been an eye witness of several persons kissing his hand. His standard 
was set up on the 19th ingt. at Glenfinnen, on the borders of Moidart, the country where ho lanued.

I had writ thus far when a messenger from Margate brought the good news that the King landed there about half an hour after three this morning, and would be at Kensington within two hours. Accordingly His Majesty arrived there about two o'clock in perfect health, and really I think I never sap him look better in my life. He appears also to be in very good humour, and to value himself upon the haste he has made to us, when there was any apprehension of danger effecting this Country. I have not time to add more, except that his Majesty told me the election of an Emperor stood fixed for Monday next, and that $I$ am ever,

My Dear Lord, most affectionately and faithfully yours,

\section{HARDWIOKE.}

Is it not time for the Pulpits to sound the Trumpet against Popery and the Pretender?

II.

The Archbishop of York to Lord Hardwicke.

Bishopthorpe Sepr 71745.

My Lord,--I am extremely obliged by your favour of the $81^{\text {st }}$ of Angust, and must take the liberty to trouble you with my most early acknowledgment for it. We received here great consolation from the King's arrival, and are in hopes that it will give some stability to the Public Affairs; as His Majesty has fulfilled the duty of a good King in quitting his insignificant Electorate for the honour of his Crown and the safety of this great People. I hope he will meet with a suitable return of Duty and Affection from them, for indeed, my Lord, the times demand a perfect intelligence between Prince and People. I was gled to hear, as I do from several hands, that the King is so well and cheerful, and his Court so gay; I would to God they would contrive to communicate some share of this fine spirit to the country, where we meet with nothing bat sadness and mortifying forebodings of danger, with little or no life or disposition to action. The common topics of conversation for the whole summer have been extremely disagreeable, and no company has come near me (and your Lordehip knows my correspondence is chiefly with the friends of the Government), nor have I gone into any company, but instantly we fall upon the disaster at Fontenoy; the perfidy or the weakness of the D[utch]; the frightful progress of the French King, and the ruinous consequences of our engagements on the Continent. To these hsve been added the perilous situation of our troops abrosd, an evil the more felt, and more atrongly aggravated, since the alarms from Bootland have taken place, and your Lordahip may imagine how ready some people are to point out the absurdity of being left defenceless at home, from the absence of those very troops, the reason of whose support in the kingdom was our home security. As to the Scotch affair, I hope of itself it is not considerable, and that Cope will soon give a good account of the rebels there; and, to be sure, the Court have substantial ressons for their security, and, if it can be, for their infidelity on that 
head, but your Lordship wont be angry, if I communicate to you an Intelligence directly from Edinburgh from no insignificant hand, that the rebels have plenty of money, are bold and desperate, and that the King's friends among the Clans are afraid of arming, and, but for that fear, the Grants and Campbells could have crushed the rebels instantly. I feel too a great diffidence in Cope, and a sort of persussion, that if they gain the advantage of him, the whole country will be their own, as far as Stirling. I pray God, all this may be ill-grounded, and that the next Post may bring good news and set our minds at ease. I find the $\mathrm{D}$ [utch] forces are hastening to our assistance. We will accept their help, but are we never to stand upon our own legs again? And upon every occasion of danger must all Europe be told, what I hope to God is a lie, that the King has neither the hearts nor the hands of his own people? For my own part, I own I heve always looked upon this as a pitiful measure of Government; I think I see that it is like to become a hateful one; and, considering the conduct of the Government, and their present connection with France, it is certainly a very disreputable-God forbid it should turn out a dengerous - expedient. Surely these low applications to the $\mathrm{D}$ [utch] must destroy every degree of our credit and influence with them, and they must look upon us, after all our blustering, as their inferiors.

I thank your Lordship for the intimation in your postacript. So far as my example or monitions can go, I shall not be wanting in my duty, but your Lordship will give me leave to observe, that Preaching will be of little avail, where the countenance of the Magistrate is wanting. To say the truth, I think his immediate help is necessary in a place where the numbers and spirit and boldness of the Papists is such, that their public Mass House joins in a manner to the Cathedral; their service is performed daily there, and their congregation formed by the same public notice, and their congregation as large or larger than that of the Protestant Church. In this respect I doubt the lenity of our Government has almost proceeded to Establishment, and the check that gentlemen received last year in their prosecution of the Papists agreesbly to the King's Proclsmation has cooled their spirit. As to their present actings, I believe the wolf must be actually at the door, before they will rise off their seats to guard against him. This I think I see as plain matter of fact. I beg of your Lordship to forgive the length and impertinence of this letter, but the wisest men know sometimes how to profit by the suggestions of weak ones. I own, I am frighted at our present sitnation, and it looks like a demonstration to me, that we are now, as to the health of the Body Politic, in the condition of a man who does not ask his doctor whether he may recover, but how long he thinks he can hold ont. I am sure your Lordship will not imagine by these observations that I am going to list myself among the factions. I scorn it. I will ever be dutiful to the King, and faithfolly grateful to my friends, who will not be displeased with me for speaking like an honest man, though a weak one. I will answer for my Heart, though I cannot for my Head. It is always my heart that dictates, when I subscribe myself,

My Lord, your ever obliged and most faithfnl Friend \& Berv ${ }^{t}$

Tho: Eвor: 
III.

Lord Hardwicke to the Archbishop of York.

Powis House, Sep $12^{\text {th }} 1746$.

My Lord,-I lay hold on this first opportanity of returning your Grace my sincere thanks for your very honest, friendly and wise letter. The zeal you express for His Majesty, his family and Government, and the affection and regard you show for your friends, are very becoming your character and known principles; which set your Grace far above the suspicion of acting amongst the factious. At lesst you are secure against any such imputation from $\mathrm{me}$, who have often insisted on most of the topics you mention, and very lately in that place where it is most material to say them. As we so well agree in our sentiments, I will not trouble you with going through the several points, but wish that imminent danger may teach us to correct former arrors.

His Majesty did a week ago yield so far to the advice of his faithful servants as to order six Regiments (i.e. 6000 men) of his British troops to be brought over from Flanders, with Sir John Ligonier at their hesd, for the defence of this country. I know this will be some consolation to your Grace, especially as the Lords Justices bad some time ago sent our transports to Williamstadt, and they are actually ready to bring them over, so that they may be here with the first fair wind. But you will be surprised when I tell you how this messure has been misrepresented;that it is deserting our Allies, and giving up the common cause; and the Ministry ought to be impeached for it. As if Great Britain was any otherwise essentially concerned in the common cause, than as the support of it tends to her own preservation; or the whole common cause would not be absolutely lost, if $\mathrm{G}^{\mathrm{t}}$ Britain (from whence it derives its strength and treasure) should become a prey to the Enemy? And, as to the Ministry, I could draw a much better Article of Impeachment for leaving the country so unguarded, though even this they could not help.

The rebellion in Scotland proceeds. The numbers of the rebels increase, and the young Pretender is in possession of Perth, and I wish they may amuse themselves there for some time. I believe indeed they are not all armed with fire arms, and that (with the blessing of God) they might be easily subdued with regular troops; but without regular troops, I see not how. Some of the Dutch forces are sent to Leith, and we expect the rest in the River tonight or tomorrow morning, the wind being fair. You see how Cope has marched eastward to Inverness. I make no reflections on it, and he justifies himself and is now marching back again. Instead of being joined by the Clane of Grant, Lrord Reay and Lord Sutherland, he has been joined only by Sir Robert Manro's son and brother with 200 men, much to their honour I But, what is more surprizing, advice is received that Lord George Murray, the Dake of Athol's brother, who was in the rebellion of 1715 , and pardoned, and has lived ever since with his brother the Dake, and has received favours from the Government, and also a brother of my Lord Danmore, have joined the rebels. What symptoms are these? And those, I mean of the King's friends, and some of his servants, who at first propagated the spirit of incredulity, do now, with the same views, represent the affair as dwindling; that the 
rebels are a despicable rabble, crushed with all the in the world. It is the duty of everybody, much more of those in employment, not to scatter terrors; but when there is a strange lethargy and deadness, and the spirit of the nation wants to be roused and animated, opistes should not be administered to them.

This brings me to the latter part of your Grace's letter, which relates to my postscript, in which too I do, in a great measure, agree with your Grace. The case of the Papists, as you state it, and as I have heard of it before, in your great city, certainly calls for the interposition of the Magistrates ; and one would think that a fer examples would keep such an enormity under. Bat the true difficulty as to the secular arm in England lies in this:-the laws against papists, as they stand in the statute book, are so severe, that they are the cause of their own nonexecution. I am sure your Grace will do everything that zeal, directed by knowledge, can warrant, both by your exsmple and your monitions. In order to show you what is doing in this part of the world, I send you enclosed three papers. The letter to the clergy of the diocese of Canterbury I will make no observations upon. The Salisbury one has more spirit. But that which meets with the most applause is the London one. I submit it to your Grace's consideration whether you will not think it proper to do something of the same kind in your own diocese ; and, if you do, I am sare it will be sach as both for matter and manner will deserve the approbation of all true friends to Liberty, the Protestant Religion, and the Protestant Succession. One thing I have slways observed is:-that representing the Pretender as coming (as the truth is) under a dependence upon Frenoh support; I say, stating this point, together with Popery, in a strong light, has always the most popular effeot.

I believe I have tired your Grace, and my time will not permit me to add more, except the sincerest assurances that I am ever,

My dear Lord, most faithfully and affectionately yours,

HARDWIORE.

IV.

The Archbishop of York to Lrord Hardwicke.

Bishopthorpe Sepr 181745.

My Lord,-The history of the enclosed paper, which I trouble your Lordship with, in a fow words is this. As I had received repeated and clesr and concurrent evidence of the distress of Cope in Scotland, and the increase and strength and progress of the rebels there, I thought it my duty to communicate it to the Lord Lieutenant and other gentlemen of distinction in the West Biding. Their intelligence as to Scotland, though not quite so particular as mine, agreed in the main with it, and was sufficient to give them a very strong alarm. A meeting was agreed upon at Birom, Sir J. Ramsden's seat, for Wednesday morning, where were present; Lords Lonsdale, Malton, Irwin, Galway; Sir Rowland Winn, Sir William Lowther, Sir John Ramsden and myself. The evidences were produced and compared together, and at the same time the information which his Grace the Duke of Newcastle thought proper to communicate to Lord Lonsdale concerning the preparations from abrosd; and Lord 
Malton produced His Majesty's Commission to put the country into the best postare of defence. All these things being laid together, it was the unanimous opinion of all present that something should be done to animste the King's friends, and, if possible, to repel the enemy, if it should please God they advanced npon us. The first step, in the common opinion, was for the Lords Lieutenant to advertise a general meeting at York, and there it is their intention, I believe, to enter into an associstion agreesbly to His Majesty's direction on the Commission, and to engage in some measure of defence, to be adjusted previously to the meeting, and these to be prepared. As the application is to the Clergy, as well as Gentlemen, I thought it became me to sign, with the Lords. The $24^{\text {th }}$ was the soonest and most commodions day. The advertisement will bo worked off todsy and distributed as fast as possible. When I returned from Birom, I communicsted the businese to Lord Burlington, and Lord Falconbridge, and went myself yesterday to Iord Carlisle, who approved the step extremely, and I have no resson to doubt but the meeting will be such as will give a Life to the King's friends. If there has been any error committed, it was not through want of real, but judgment. If the thing be right, I leave it to your Lordships judgment whether it wont be proper to approve it, to the noblemen concerned in it, and to give any orders from London that may be thought proper, before the meeting. Your Irordship is quite right in your notion of the pablic lethergs, and I mast take the liberty to say, that the gentlemen of this country, who are His Majestys stannch friends, apprehend too little attention is paid to this affair above, and too little care taken to communicate right information. The rebels are certainly bold, and the Kings troops in the command of a man who (as the soldiers say who have served in Bcotland) has shown most nosoldierlike conduct. The acconnts here, of the $7^{\text {th }}$ inst from Edinburgh, are that the rebels are 7000 strong; that perheps is the number of Fear, but it is certain, that transports were that day getting ready at Edinburgh to bring Cope and his men by ses from Inverness.

I am, my Lord,

Your Lordship's most obliged and faithful servant,

Tно: Eвов:

V.

The Same to the Same.

Bishopthorpe, Sep 151745.

My Irord,-It is a prodigious satisfaction, and gives a great stability to my mind, when I find my sentiments agreeing with your Lordship's. Before I received your Lordship's I hed printed and dispersed a short admonition to the Clergy over part of the diocese here, and must now continue it without alteration, but it displeases me prodigiously both se to the matter and the manner of it. It is indeed nothing more than a sort of Direction that I received from his Grace of Canterbary, with two words of my own at the end of it; and the reason of this was not neglect or coldness-his Grace's Monition was the very first thing of Authority that astisfied me as to the reality of our present danger from abroad, and as there is a great delicacy to be observed in matters of a public 
nature, especially when commanicated to the Clergy from their Diocesan, I kept religiously to his word, who spoke, as I imagined, from the Conncil Board. If I had received the intimation sooner, and in a more direct manner, from the proper fountain of intelligence, I think I should have made a better use of it; I might perhaps have thrown out something warm and injudicious, and that at this juncture had been better than the cold phlegm of an old man. I know how full the heads of the administration are of more important matters, but I must beg the favour of your Lordahip to intimate to my noble friend, the Duke of Newcastle, that I hope, as he has contributed to place me in a station of some eminence, he will support me in the figure of it, and let me know things which it imports me to know by some other canal than that of Canterbury. Your Lordship sees I am a little warm, but I will thaw my resontment by donbling my industry to serve my Royel Master and the frithful friends he confides in, and I hope one means of doing it will be to render this intended meeting in Yorkghire of as much importance as I can. I am considering how to make it general, and to that end, as I know and converse with men of both parties, and with equal civility, I try to recommend it to all as a case of common danger. I hope I shall succoed in it in some measure. Mr Fox speaks heartily, so I hear does $M^{r}$ Wentworth. I have wrote to $M^{r}$ Dawnay, Lord Downe's guardian and ancle; I have wrote too to the Lord Mayor and Aldermen, and think I see a spirit of concurrence in many people of that Denomination, and I took it for no bad omen on our side, that York was much illuminated on the last news from Frankfort.

Lord Falconbridge dined with me yesterday and expressed a perfect unersiness for the honour of this moeting, and will give it all his credit. He offered a sort of security for the honour and innocence of his relation and neighbour, Lord Fairfax of Gilling, and intimated to lodge a deposition with me. I told him that was a matter of some nicety, but whatever I saw in favour of Lord Fairfax, notwithstanding my good opinion of him, must rest upon his suthority. I purpose to go on Tuesday to Temple Newsome to meet some gentlemen there, and settle previously the business of the meeting, in which the lords have all offered their assistance. I enclose Lord B[urlington]'s letter, which I am not quite plessed with. For, though $\mathrm{M}^{\mathrm{r}}$ Arundel was with him when he received mine, there is a coldness of Indolence or Incredulity in it.

If the present Administration should quit with no other imputation on their conduct than that of calling the forces from Flanders, they will certainly be canonized in this country; and the contrary conduct is as arrant rodomontade as ever was practised in the world. I hear from Scotland, that the plan there with the rebels is to magnify their expectations from England; I hope it may have no other foundution but keeping ap the spirits of their ruffians. A very great man told me, that when he mentioned this Scotch tamult to Norfolk at Scarborough, he flouted it, as the errant in Romance; but added, that he could not answer for what might be done four or five years hence, if France got possession of the power they aimed at. This I think is matter of some observation for a Protestant. Give me lesve to tell your Lordship a very short story I have heard. When the $D$. of Gordon gave his Bailiff orders to bring 
in his Clans for the King, the Bailiff drew his poignard, and told his master he would stab him, if he pressed that matter further, for all bis clans must go upon another service. A story incredible enough, bat a little truth in it would show the inveteracy of those people. Well, be they as inveterate as they please, I hope we shall deal with these beggarly fellows unassisted, but when I think of descents from abroad, Totus tremo horrescens. Pray God preserve us from the insolence and tyranny of France !

If his $G$ [race] of $N$ [ewcastle] or your Lordship have any commands for me previous to this meeting, for as the world goes, it may be a matter of moment, you will plesse to communicate them to,

My Lord, your ever obliged and faithful Friend \& Bervant,

Tro: EвоR.

I am told from good hands that there is a fine train of artillery at Berwick; God forbid it should fall into the rebels' hands, and be pointed against England. The stopping of the rebels in Fife must be owing to fear, or weakness, or design, or expectation of assistance. I pray God their reason may be of tha first sort. There is a report in this country, of what authority I know not, that if Cope had attacqud the fellows at Coriariek they were so well provided, that they would have torn him to pieces. However it is the general opinion that even in that case he ought to have retreated southward.

VI.

Lord Hardwicke to the Archbishop of York.

Powis Houвe, Sep 171745.

My Lord,-The proofs of zeal and vigour for His Majesty and his Government, which appeared so laudably in your Grace, and in the other Lords and Gentlemen, who met at Sir John Rameden's, and which are so fully expressed in your letter of the $18^{\text {th }}$ inst., gave me the greatest pleasure. They have also given grest satisfaction to His Majesty, and his Ministers, and I think the measures you have already taken, and also those you have further resolved upon, are extremely right. The only doubt I have heard made is whether the certainty of the intelligence of a foreign invasion is not rather too strongty expressed in four printed paper. But if that shall only tend to awaken and animate the friends of the Government to a greater degree of vigour in its defence and support, the effect will be good. I don't imagine you could appoint your day for the meeting at York earlier than the $24^{\text {th }}$ inst., and $I$ hope it will be very numerous and hearty.

Your Grace was extremely right in msking the cunmunication which you made to my Lord Carlisle, my Lord Burlington and Lord Falconbridge; and I take it for granted that you will heve their company and assistance. Undoubtedly all the proper steps will be taken to signify to the Lords and Gentlemen, who have acted so meritoriously, the approbation and thanks of the Government; but I don't see what orders can be sent from home in the meantime, especially as my Lord Malton has His Majesty's Warrant in the manner he desired. One thing indeed might be done, which is Letters from the Lords of Council to the several 
Lords Lieutenant to have the Militia in readiness to march, which, as a Council is to be held at Kensington to morrow, may then be considered. Letters of that kind were sent ten dsys ago to the Lords Lieatenant of the four Northern Counties, bat it seems a diffioulty has been raised by some of them upon the month's pay, advanced in those Counties in the year 1715 , not having been repaid to them. If this difficulty is stood upon, it msy make it more necessary to draw out the militis of Yorkshire, who, I take it, are not in the same arse sa to that point.

At this Council I apprehend the Parlisment will be sppointed to sit to do business on the $15^{\text {th }}$ or $17^{\text {th }}$ of October, which is as early as possible.

Your intelligence that makes the number of the rebels 7000 is certainly the voice of Fear, or a voice spread to excite Fear. Possibly they may be about 8000 , though some accounts make them fewer, and a great many not to be armed with fire arms. The letters of yesterday bring advice that they are marched from Perth to Dunblane, and that their design seems to be to pase the river Forth somewhere above Stirling, where it is fordable, and so to march into England on the side of Lancashire. Though this cannot be relied on as certain, yet it makes it necessary for the Government and all its friends to be upon their guard. A Dutah mail arrived this day inforne us that the first embarcation of the Dutch troops (viz 5 Battalions) sailed from Williamstadt on Thursday last, and that they imagined that they were already in England. From hence we hope that the last orders have met them at sea, and thet they are all sailed for Leith, wo land theresbouts.

Though I hare above hinted the writing letters to the Lieatenants of the three Ridings for raising the Militia, yet I am far from saying that measure will be taken; neither am I clear that it will be right ; for if it should heppen to interfere with your scheme of raising voluntary troops by associations, it may do more harm than good. Therefore all I say is thet it will be considered tomornow.

I pray God prosper your undertakings and am ever most truly and affectionately,

My dear Lord, your Graces most obedient \& most faithful humble Servant,

HARDWICKE.

VII.

The Archbishop of York to Lord Hardwicke.

Temple Newrome Sepr 171745.

My Lord,-I came hither to-day to confer with Lord Irwin and Sir Rowland Winn upon the methods of making the meeting of the $24^{\mathrm{th}}$ (which is likely to be a very grest one) of as much credit and use to the Kings affairs as may be. It has been agreed to settle the matters to be proposed at the geueral meeting previously the day before at my house at Bishop Thorpe, and such Lords and others will be invited to it, as are like to give judicious and cool adrice, and sach as understand the county. I am apt to think an Association will be the first thing agreed on, and I hope some present methods of defence, in case the mischief gathers strength, will immediately be entered into. Some soldiers of experience 
and affection for the King will be called upon to assist and form a practicable plan of self defence, which, it is hoped, will be supported by a subseription. If it plesse God to give a good turn to our affairs befory that time, this meeting in favour of the Government will have ite use, and show the Kings enemies, both at home and abroad, that His Majesty has one County, and that a great one, that will stand by and support him, in time of danger, at all hazards. I have got somewhat deep into this affair, before I was aware of it-I will do the best I can to carry it through, and, be the event what it may, nobody can rob me of the satisfaction of having discharged, as I was able, my duty to the Public. I purpose calling apon $\mathrm{M}^{\mathrm{r}}$ Fox on my way home tomorrow, and inviting him to the conference; For I have all along inculated, that for the present all party considerations should be buried, and nothing attended to but the public safety. I send your Lordship a letter trom Manchester, communicated by Bir B. Winn, who sssures me thet his correspondent is a man of understanding and integrity. I euclose too the Pretender's Deputation of his son, and his Bons Declaration.

I am, my Lord, your Lordships most obliged \& affectionate Friend and Bervant,

THO: EBor:

VIII.

The Same to the Same.

Bishopthorpe, Bepr 211745.

My Lord, $-I$ have the honour of yours of the $17^{\text {th }}$ inst, and shall let the Lords know, in the best manner I can, how satisfactory their intended service is to His Majesty, and hope the meeting will prove of great use at this perilous season to the country in general.

The strong assurance of the danger fronl abrosd was judged to be agreeable to the intelligence from London, but, for my own part, I had some inward doubts about it. I did not explain them; for as the Nation was in a lethargy (not jet I doubt full awake in the Bouthern parts of it) I thought it best to use such words as might tend to rouse them. If it is mendacium officiosum, I shall die without compunction sbout it, for those Powers are habitually bent on doing us all the misohief they can, and I wish experience msy not show us, thet the expression in the advertisement was not too strong, but premature.

I hear from all hands that the Meeting is like to be very general, and it is hoped, very unsnimous. As I am in some messure embarked in conducting it, I begin to be very solicitous for such an issue of it as may be most for the service of the Public and the honour of the King. I believe a strong Association will meet with no difficulty; but I have my fears about a subscription for present defence. The money must be paid npon the nsil, and in the quickest way; a body of Forces, Horse \& Foot, they say will be three weeks or a month in raising. The Association in 1715 is now before $\mathrm{me}$, and, mutatis mutandis, will be copied in this. That was followed by issaing proper commissions, and raising the Militia. Most of the Lords, I believe all the Protestant ones, will meet here early on Monday morning to settle the measures for the next day. Your Lrordship may be sure I shall oppose nothing, bat for- 
ward with my best abilities the most vigorous resolutions, but yet zeal must take counsel of prudence, and nothing should be proposed, but what the gentlemen of the County are sure can be carried into execution. There must be no debating at the General Meeting: I would to God, a large and exemplary subsoription were practicable: if not, it is my opinion, that the stop should be at the Association of people who come together unanimous, sent home again in good humour, with an honest alarm upon their minds that the danger is real, and a resolution, if needs be, to stand up against it. $M^{r}$ Fox and $M^{r}$ Wentworth, members for York, are with us, and Mr Dawnay, Lord Downe's guardian, and yesterday the Lord Mayor and Aldermen, a committee of them, came from York to assure me that they would give the meeting all the countenance and help they can in the body. I hope the King will have very strong sasurances of a general obedience snd attachment to him in this country. Since the news of taking Edinburgh, we have been relieved by hearing Cope is at Dunbar. He is now in his proper part, and I hope will at least stand as a barrier to England, bnt yet I wish to God, every soldier of the King's were here to cover as instead of BrabantGod forbid we should be in the position of the man who is busy patting out the fire in his neighbour's house, when the flames have seized his own! I am afraid of nothing so much as treachery; if that be stirring, the King's friends must be more stout and vigilant.

Your Lordahip will forgive me, but I cannot help hinting to you, that the great people of this County think that the intelligence to them from above is not so direct and anthentio as they could wish it. Certainly, my Lord; we are in the most imminent danger, and I am informed from all hands that the Papists, who met at Stockton races, are in high gpirits, and I could give some instances of insolent beheviour from them. I pray God direct the minds of the King and his faithful servants to put a speedy and effectual end to our fears and our dangers.

I am, my Lord, with all possible affection, your Lordships most obliged \& faithfol Friend,

Thо: EBor:

I cannot be essy without saying another thing to you. I have heard the security at London censured in this manner in several parts of this country :- Why should we stir to support a Government that does not seem to believe its danger, or be inclined to support itself? God forbid this should run.

IX.

Lord Hardwicke to the Archbishop of York.

Powis Houso Bepr 21 "t 1745.

My Lord,-I owe your Grace a thousand thanks for the letters, the first of the $15^{\text {th }}$, the later of the $17^{\text {th }}$ inst, from Temple Newrome; and have taken care to keep His Majesty particularly informed of your landable zeal and activity in his service, of which he yesterday did to me express himself highly satisfied, and spoke with the utmost approbation and praise of the part which your Grace so worthily takes in this critical juncture.

I now proceed to answer your letters in order. I know your Grace 
does not suspect the Duke of $N$. of any design not to meet you with the greatest regard, and I am sure you have no resson for such a suspicion. You will permit me to say that your imagination that the Archbishop of Canterburys Monition procede from deep consultation at the Council Board, is a little mistaken. No other intelligence was conreyed to him or any of the Bishops but the Recital contained in His Majesty's Proclamation against Papists, and it was left to every Bishop (bow rightly I wont say) to act as he pleasod. And your Grace must observe that the Canterbury letter extends only to the Clergy of that diocese, and not even to the whole Province; and the Salisbury Monition expressly refers to the Preamble of the Proclamation. If there had been any general meesure, you may be assured I should have taken care to have informed yon earlies than I did. But this is now become quite immaterial, for the activity your Grace shows, and the acts you do, are ten times more importance than a printed paper.

As to your General Meeting at York, I think entirely with you that it is right to make it as extensive as possible, and to take in men of all parties and denominations, who are not Jacobites. I lay more weight upon the evidence and eclat that will arise from such meetings and Associations of the zeal and spirit, and good affections of His Majesty's subjects in support of his Government and against the Pretender, than upon the military atility of their troops, without however excluding that. For I think it materisl to convince Foreign Powers (as I told the King today) that the appearances in Englend are very different from those in Bcotland, and that they will be mistaken if they take their mesenres from the latter. I return your Grace Lord B[urlington]'s letter. I take the coldness and dryness of it to proceed from the indolence of his temper, rather than from any other motive. Men must be taken as they are made. For these reasons I have not spoken of it to anybody, and should think it best for your Grace not to do so.

It was not thought proper to send any orders for raising the Militia in Yorkshire, for the reason hinted in the conclusion to my last-lest it should interfere with your scheme of Associations and voluntary troops, which indeed I believe to be a more effectual method.

By the contents of your last I think you are proceeding in a very right method, and a previous Conference of proper persons to settle preliminaries cannot fail, in my opinion, to bring things to some procision, and to have a good effect.

I have communicated a copy of the Manchester letter to the Duke of Nepcastle, who writ to my Lord Derby lest night by express.

I am glad your Grace is engaged deep in this affair. You cannot be engaged too deep when so much is at stake; and I sm sure your wisdom and prudence will so regulate your conduct thet it must end to your own honour, as well as the public service.

I dont wonder the Papists shonld sffect to represent this rebellion as trifling, in order to bring about the neglect of it. But that Persons, who protest more zeal for the King, more flattery to his prejudices, and to enjoy more light of his countenence than others should do so, is astonishing. It is something like Count Kannitz, the Queen of Hungary's Governor at Brassels, and the French General, by an odd concurrance, 
sending orders to stop the making the great inundation at Ostend, on the same day. It is the talking of it down, and representing it as nothinga rabble that might be crushed in an instant, and dissipated of itself, whioh, in my way of thinking, hes brought it to the height it is at. The industry of some people hes, for this week or ten deys past, represented it as dwindling, and dying of its own weakness; and yet on Thursday about midnight an express arrived, which gives us the strongest resson to believe that the rebels are before now in possession of the City of Edinburgh, the Capital of Scotlend, and some accounts add that they are more than 5000 strong: I fear that in Edinbargh they will find friends, money and arms. However, I rather like that they should amuse themselves there than march for England. But let me turn the medal, and show your Grace the better side. Cope with his troops are come back, and landed on Monday night at Dunbar, and joined by the two regiments of dragoons; so that he was south of the rebels, and within 20 miles of Edinburgh. We expect every hour news, of some action. God grant it may be more soldierlike than the march, and a successful one ! The last embarcation of Dutch troops (viz. the other four regiments) arrived this morning in the river. Some of the first are marching for Lancashire; one is gone by sea wo Cope; and two regiments of those left will be sent to Newcastle. There are letters also come to the Admiralty that one half of the British troops embarked at Willemotadt on Wednesday last, and the rest now there were to embark on Thursday ; so that, the wind being now fair, we expect those $6000 \mathrm{men}$ in the river every hour.

As to the story your Grace has heard relating to the Duke of Gordon, it is well known bere. It was not the Bailiff, but one Gordon of Glenbucket, a vassal of the Duke's, who was in the rebellion of 1715 , and is gone into this; and your story is in substance true. A monstrous instance of a very old, bat hardy, daring Highlander.

I had writ thus far on Friday night when an express brought word that the Protender's son with his rebels marched into Edinburgh on Tuesday morning, and was proclaimed there, and was lodged in Holyrood House. This is no more than I expected; but the same express says they are now not above 8000 men at most. Cope's army was all landed; the two regiments of dragoons had joined him; and the transporte with the Datch Battalion were seen the same day off Tynemonth. But Good God I what a figure does this Country make, when such a rabble has overrun one Kingdom, and taken possession of the Capital, and what an encouragement to foreign enemies to invade us!

I am called away, and can add no more but that I am, with my whole heart,

My dear Lord, most faithfully and affectionately Yours, HARDWICKR.

$\mathrm{X}$.

The Archbishop of York to Lord Hardwicke.

Bep 271746.

My Lord,-It is a trouble to your Lordship, but permit me to write to you, as it is a relief to me. The Spirit of the Country is prodigious, 
and we are all in motion from one corner to the other, and the Lrords will certainly do their duty. The city is so much in earnest, that they will make of themselves a considerable purse, and put between two and three troops into action. The Lord Mayor told me yesterday, that the lowest of the Citizens contributed something. Oglethorpe is here, and hes persuaded thirty or forty young gentlemen volunteers to follow him to Berwick, a sort of Hussars. They are to rendezvous at Knavesmire on Monday morning, have a Ball at night, and march on Tuesday morning. We must leave it to the general to consider whether a Ball will inspire or enfeeble his myrmidons; but let the spirit of defence go forward. Mr Wood came to me last night, with a message from Lord Burlington. He is now, I believe, sngry with himself for not being at the meeting, and I believe thanks me at his heart for answering for him in the hearing of the county. $\mathrm{He}$ hes sent his subscription, and is certainly a warm friend. I have sent a minute of the previous transaction to the D. of Somerset, as I have partly done too to the Earl of Ailesbury.

I concesl it, bat I own I conceive terrible apprehensions from the affair at Preston Pans, where the conduct of our General was-I wont give it the right name, but that of the rebels excellent; and from what I can collect, and the judgment which I form upon the opinion of the soldiers here, they are admirably disciplined; and, our men have felt it, well armed. Their resolution and conduct in taking the little battery was admirable, and, as they are keen and savage, their leaders well know how to point their strength properly and effectually. There is something too in their artful taciturnity that alarms one, and they say, it is fact, that from their setting out to this hour, it is not easy to say who leads them, and they are not seen, in a manner, till they are felt, so silent and well concerted are their motions. I hope in God all this is known above much better than it is here, and that it is now seen that this rebellion is not to be quashed by small platoons of an army, but must be attended to totis viribus. Who can say what would be the consequence of such an advantage gained in England? What shall we think of the behaviour of the Scotch nobility upon this occasion? Strong marks of treachery, my Lord, when they fled their country, which they might have saved by only standing up in Edinburgh in their own defence, and lending Cope their advice and conntenance. Lord Loudon is an exception to this, who has behaved like a brave and honest man. Some of the Papists here I am told have subscribed-Timeo Danaos et dona ferentes. The power of some of them is very great, and it must be left to the wisdom of the Government to consider whether Tempest of the W. Riding near Skipton, against whom an information of arms has been lodged on oath, and who is said to be very artful and zealons, should not be secured. I am told too that Constable of Holderness, Dunbar's heir, has a troop of three hundred at his command. Dunbar was seoured by Lord Irwin at Hull in the year 1715. Lord Conyers D'Arcy told me yesterday, that young Duncombe had desired a commisaion, which may be a great accession of strength in the N. Riding. I write in some agitation of spirit, but I would do as I have done, were the rebels at Northallerton, 
and, by the grace of God, will die rather than live ander a French Government. I hope Lady Hardwicke is in spirits.

I am, my Lord, your most faithful Friend, Tно: Евов:

We have it from undoubted anthority, that the meeting at York on the $24^{\text {th }}$ inst. was the most numerous that was ever known, being composed of almost all the nobility, Gentlemen and Clargy of that great County. It was conducted, as the occasion required, with great seriousness and quiet. The Asbociation was signed most heartily and unanimously, and the subscription, which is going on, was very large and cheerful. The City of York showed a laudsble example apon that occsaion, the Lord Mayor and Aldermen undertaking to raise and maintain troops for their own defence. The town of Kingston on Hull is resolved to do the same. There appears at York a fine spirit in a set of brave young gentlemen, who purpose to act as volunteers in the service of their country, and began to form themselves on the very day of the meeting.

The foregoing paragraph contains matter of fact, and I submit it to your Lordship whether it is not proper to be inserted in every newspeper. If so, your Lordship will be so good as to order it.

Besides the general sense of the danger, it is thought the spirit and courage of the people was raised by the newg of the action in Scotland, which appears to have been a surprise, not an engagement. The brave English were butchered in cold blood, a plain proof of the savageness of the rebel Highlanders, and that their leader is a man of blood.

This is grounded upon hearsay, and I should think, if true, not improper to be annexed to the other, that the natural indignetion may run like wildfire. The intelligence from Berwick is, that the whole affair was over in twelve minutes.

\section{XI.}

Lord Hardwicke to the drchbishop of York.

Pourls House, Sep 28, 1745.

My Lord,-I return your Grace my hearty thanks for the honour of your letter and the several inclosures, which I received yesterdsy morning by flying packet. In this gloomy and melancholy season, nothing could possibly give me so much satisfaction ss the uncommon zeal and ardour which has been shown, by so numerous a representation of your great and loyal County of York, in the cause of their King and Country. God grant that the glorious example they have set may be followed by other counties ! But I own I feel a particular plessure in the great and noble part which your Grace has taken on this occasion, and in the gallant, wise, and becoming manner, in which you have exerted yourself. I was so full of it, that I went immediately to Kensington, and gave the King an ample account of it in his Closet. I found him apprized of it by the Lord Lieutenants letters, which he received from the Duke of Newcastle; but he was so pleased with it that he desired to hear it over egain. I informed his Majesty of the substance of your letter, the sermon your Grace had preached last Sunday, and with such prodigions expedition printed and dispersed; and when I came to your speech, he

voL. XIX.-NO. LXXY. 
desired me to show it to him. His Majesty read it from beginning to end, and gave it the just praise it so highly deserres, and said it must be printed. I said I believed it was printed at York, but it is determined to print it in the Gazette. If in this my commission be exceeded, I plead my Master's commands, but I hope your Grace will not disapprove it, since my sincere opinion is that it deserves to be so published, and that the topics and animated spirit of your composition are calculated to do much good. When I had gone through this part, I said :-' Your Majesty will give me leave to acquaint my Lord Archbishop that you approve his zeal and activity in your service.' To this the King answered quick :- "My Lord, that is not enough; you must also tell the Archbishop that I heartily thank him for it.' Hia Majesty also highly applauded the zeal, affection and unanimity which had appeared in the severaI Lords and Gentlemen on this occasion; the Association; the largeness and generosity of subscription; the union of all parties, and the general conduct of the whole; and doubt not, bat the seme zeal and industry will carry this good work through, and complete the utility of it; for which no assistance or powers from the Government will be wanting. But these matters will be properly taken notice of and answered by the Duke of Newcrstle to the respective Lords Lieutenants.

His majesty also took particular notice of the good affections and vigour expressed by the Lord Mayor, Aldermen, and City of York, which are highly agreeable to him.

It is a most happy circumstance in this affair that the unfortanato and shameful defeat of our forces under Sir John Cope did not cast a demp on your meeting. As it did not, the spirit and success of your meeting will I hope give new spirits to the people, and abate the ill impressions of 80 tragical an event; just as the providential arrival of the British regiments from Flanders furnished a kind of armour to us in London against the first shook of that bad news. If those troops hud not come in the critical moment, God only knows what would have been the terror and confusion here. Let me tell your Grace, for your further comfort, that eight British battalions more, and 1500 dragoons are actually ordered to be brought over immediately ; transports are already provided here; and other transports are ordered to be taken up in Holland, so that they may take the opportunity of the first fair wind. I know some frionds of yours, who have talked themselves hoarse in contending for this measure, and whose early advice, if followed some time ago, would have prevented, in all humen probability, this dismal scene. But the conduct of some persorks on this occasion has been infamous. Howerer I hope in God it is not now too late : a grest body of forces will forthwith be sent to the north, and some of them are actually on their march. I contend every where that they must be a great body ; for the King's Crown; the protection of his People; the work of the Revolution, which has been building up these seven and fifty years, must not be risked upon an even chance.

Your Grace sees by the printed papers what has been done by the merchants of London to support the Bank and thereby the public Credit. It is a step that never was taken before, and has had a prodigious effeot to stop the run which was begun.

Wo know nothing here of the Castle of Edinbargh having fired upon the 
town, and I believe the report is not true ; neither have we heard of any extraordinary instances of oruelty committed in or after the battle; which has induced me not to add this last circumstance to your advertisement, but I heve directed it to be published as a paragraph of news in all the papers, just as your Grace sent it up.

I am ever, with my whole heart, my dear Lord, Most faithfully and affectionstely yours,

HARDWICKR.

XII.

The Same to the Same.

Powis House, Octr 3. 1745.

My Lord,-You wrong your own good judgment when you say that. your letters are a trouble to me. On the contrary, nothing is a greater consolation to $\mathrm{me}$ in these comfortless times than to hear from your Grace, and of you. By the former one is sure to learn something material; by the latter to hear of everything that can do honour to you, and credit to your friends. The part which I take in it I hope your Grace does me the justice to feel in some messure for me.

As I trust that my letter of Saturday last ${ }^{2}$ got safe to your hands, I have little to add by way of answer to yours of 27 past. I am glad the raising of your troops goes on so briskly, and hope your corps of young hussars will prove of service. I dont doubt Lord B [urlington']s being hearty, and am very much pleased that you have writ to the Duke of Somereet, and the Earl of Ailesbury. The affair of Gledsmair was a terrible one. Pudet haec opprobria. But as to the discipline and excellent mancenvre of the rebels, dont let your people be too much alarmed with it. 'Tis cried up by one set of people to excuse their own shameful behaviour; by another, to strike terrur, and excite, if possible, a general panic. Much exaggerated by both. But I entirely agree with your Grace, that it will not be pradent nor excusable, to attempt to crash them by small bodies. You see by my last the doctrine I have preached, and still continue to inculeate totis viribus. In short I have pressed more in the Closet, and at Councils of war, on this subject, then perhaps belongs to my station. For your comfort, yon will have, to a trifle, all the rest of the British foot brought over from Flanders, so that I hope we shall have one good army in the North, and another in this part of the kingdom, to be ready against an invasion.

The subscription of some of the Papists is surprising, and your Grace's Latin observition upon it is just. Aliquis latet error; equo ne credite Tercri. It can be only colourable, and to procure some relaxation in their favour. I know nothing, nor can I find that angthing is known by others here, relating to the two considerable Gentlemen you mention. ${ }^{3}$ If the informations your Grace mentions are before the justices of the peace and Deputy Lieutenants, they know the powers which the Law invests them with, and the positive directions given by the proclamation and Letters of the Privy Council to put them in execution. Hannibal ad portas. This is no time for suspense and delay. I am glad of the Deala-

\footnotetext{
2 No. XI. above.

- Tempest and Constable.
} 
ration of young $\mathrm{M}^{\mathrm{r}}$ Dnncombe, and think it an acquisition of consequence in that part of the kingdom.

Letters came today that Gen' Guest had threatened to cannonnade the Town of Edinburgh, unless they furnished bim with provisions, and that, upon this threat, they had agreed to furnish the Castle with all they could want. This is good, provided he guards against a surprise, which he undertakes for. It is also writ that the rebels have began to commit devestations and cruelties. I pity the poor sufferers, bat the fame of it will do good. One inference I collect from their suffering the centlle to be supplied, which is, that they do not intend to stay there to compel that fortress to surrender, but will maroh forward, if they are not alresdy set out. Some letters spoke of their designing to begin their march on Tuesday last. I wish Wade was nearer to them, but his troops advance as fast, as possibly they can. I have a very good opinion of the zeal and good conntenance of your volunteer corps, but I own my reliance is, under God, on the regular troops. Your Grace's resolution is a magnanimous one, and becoming every good Englishman and Protestant. The spirit you have shown proves you are above being intimidated. You are very good in remembering my poor wife. You know we have sometimes called her Cassandra. She is in raptures with you, and, with all the rest of the family, sends your Grace her best compliments, thanks, and prishes. Be assured I am ever, My dear Lord, most faithfully and affectionately yours,

\section{HARDWICKR.}

XIII.

The Archbishop of York to Lord Hardwicke.

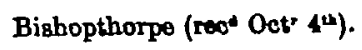

My Lord,-I shall lay it up on my memory as incomparably the most happy circumstance in my life, if it plesse God, to be of any service to the Public at this dangerons juncture, and your Lordship may be sure that I feel a satiafaction not easily expressed from having the approbation of a friend so wise and good as yourself, whom I must love and honour, dum spiritus regit artus. I took the liberty yesterday to send my Lord Mayor the passage in jour Lordships letter which expresses the Kings approbation of their doings. Though indeed they want no spur, for they have raised an incredible sum of money for this City, and will in a little time perfect their intended levy of near 300 men.

Hull has been spoken of as in a panic. Upon inquiry $I$ find it utterly false. The spirit is alive there, and shows itself in the most active preparations for defence. Nothing was ever better done, than sending Oglethorpe hither. He captivates the young fellows and the populace, and was received at his return from Knevesmire the other night with most prodigious acclemation. As the General desired it, I rode upon the ground with him for what he called Countenance.

The town of Rippon has slhowed a very good example; and as it happens to be so much under my peculiar jurisdiction, it was a peouliar pleasure to me to receive by the hands of their Recorder with the complete Declaration of Loyalty, a contribution of near $400 l$., and all this withont solicitation, which makes it so much the better. 
We were thoroughly alarmed on Tuesday with danger from the Papists, and particularly that Lord Fairfax of Gilling was on the point of rising. Search' warrants went out instantly, and returned with the fullest justification of that noble Lord; who, I believe, is the King's friend. The alarm struck the more, as we had more certain intelligence at the same time that the Papista at Egton, a little town on the Moors full of them, had made pablic rejoicings on Cope's defeat, and had all like to have been cut to pieces by the protestant ship-carpenters of Whitby.

I believe it is very certain that Choln[ondely] Turner will raise a thousand men in his own management for the service of the King in Cleveland.

I did not quite like the result of the previous meeting at Mansfield of the Notts Gentry. They wanted a Commission for their President, the D. of Kingaton, and the subscriptions waited for the example of his Grace of Newcastle. I hope it appeared, as it should do, yesterday, for at this time what is done with spirit is twice done.

I purpose, God willing, to set out from hence this dsy sennight, snd be in Town the Tuesday following, unlese your Lordship should signify to $m e$, and it should appear to $m e$, that $m y$ being her $\theta$ is like to be of any use, and, to say the truth, that I have been of any, is owing to my having offended no man in point of perty, and they happen to agree in me as Uno Tertio. I tronble your Lordship with our York Paper, for the sake of Oglethorpe's puff, and a paragraph relating to this young man's Cabinet Council, which comes to me from good hands and should be made public. Theg can't confute it, if it be wrong, bat by telling truth, and that may have its use. We have had two or three papers dispersed here from Edinburgh, from the Pretender's press, called the Caledonian Mercary. One of them consisted of a journal of his progress, agreesble to what we here know of it. Inother was wrote with great fre and popular art, as the meditations of an honest, impartial man in his aloset, raising an argument of the plain signs of God's finger in the manner and rapidity of his success. The third was a Proclsmation issued after Cope's defeat, forbidding public rejoicings in Edinburgh for the victory, as it was purchased with the blood of his own subjects. These two last were calculated to do muoh mischief. I have ordered the Postmaster to day and for the future to open these letters, when he suspects them, and undertake to justify him.

I am my Lord with perfect trath Your Lordships most faithful friend,

Tно: Евов:

XIV.

Lord Harducicke to the Archbishop of York

Powis House Ootr 61746.

My Lord,-I troubled your Grace with a long letter by the last post, and have been so much employed all this day that I have only time to answer the business part of your last. The principal point, and that a material one, is whether you should oome to Town at present or not. I have not had an opportunity of seeing the King to day, but I have talked 
with the Duke of Newcestle and several of your Grace's friends on the subject. The letters from the Lrords and Gentlemen in the North have all done you so much justice on this occasion, and every body here is so highly sensible of your Grace's eminent usefulness in those parts, that we are all of opinion that your Grace should postpone your journey for a short time at least, and that your presence in Yorkshire will be of infinitely greater service than it can be at Westminster, where no opposition is expected to any measures for the security of the King and Kingdom. You may be sure nobody pretends to preseribe to your Grace. I only lay before you our thoughts, lesving it entirely to your own judgment, which will be best formed upon the spot, where all circumstances must appear in the proper light. And in trath I dont know bat this may be a better way than speaking directly to the King, for I am so fully apprized of the high opinion of the part your Grace has acted, and of the utility of your being there, that I know beforehand what his answer would be, and that might possibly pat you under a difficulty.

I rejoice in the glorious progress of your subscriptions and levies; and am told that the second Nottinghamshire meeting succeded extremely well, and that the first was only intended to agree upon the second, which was a general one.

I like your paragraph about the young Pretender's Cabinet Conncil. I believe it is in fact true; and it will be propagated here.

I entirely approve of what your Grace has done in order to suppress the distribution of that treasonable paper the Caledonian Meroury. The like orders have been given here, and will undoubtedly be justified and supported.

I am unfeignedly, my dear Lord, ever yours,

(To be continued.)

HARDWICKE.

\section{A Report of the Battles of Jena-Auerstädt and the Surrender at Prenzlau.}

In the records of the British Foreign Office ('F. O.' no. 74, or - P. R. O.' no. 200) there is the translation of a long report on the above-named occurrences. It is not deted, signed, or endorsed in any way; but Mr. Hubert Hall, of H.M. Public Rocord Office, kindly informs me that he believes the original to have been compiled by General Bennigsen, who communicated accounts, written in a similar style, of the battle of Eylan, \&c., to his brother in London. It was probably written shortly after the surrender of Prince Hohenlohe to Murat at Prenzlau (28 Oct. 1806). Portions of it are evidently based on inaccurate first reports, and these I have omitted; but several of the details, especially those referring to Prenzlau, are of interest and deserve publication.

J. HoLtuand Rose.

The Battles of Anerstidt and Jena were fought on the seme day, but were in every respect two distinct actions. That of Auerstadt was lost 